$\mathrm{A} \mathrm{J}_{\mathrm{atas}} \mathrm{H}$

Article history :

Received : 14.02.2016

Revised : 10.05.2016

Accepted : 18.05.2016

Members of the Research Forum

Associated Authors:

${ }^{1}$ University of Horticultural

Sciences, BAGALKOT (KARNATAKA)

INDIA

Author for correspondence SIDDALINGAYYA SALIMATH University of Horticultural

Sciences, BAGALKOT (KARNATAKA) INDIA

Email : salimath.salimath@gmail.

com
THEASIAN JOURNALOF HORTICULTURE

Volume 11 | Issue 1 | June, 2016 | 186-188

Visit us -www.researchjournal.co.in
DOI : 10.15740/HAS/TAJH/11.1/186-188

RESEARCH PAPER

\title{
Screening of turmeric (Curcuma longa L.) cultivars for quality in Southern dry zone of Karnataka
}

\section{SIDDALINGAYYA SALIMATH, J. VENKATESHA ${ }^{1}$, Y.K. KOTIKAL ${ }^{1}$ AND G. RAVIRAJSHETTY ${ }^{1}$}

ABSTRACT : An experiment was conducted to evaluate the performance of growth and yield parameters of sixteen cultivars of turmeric for commercial production in southern dry zone of Karnataka. The experiment was laid out in Randomized Complete Block Design (RCBD) with three replications at the farm of College of Horticulture, Mysore. Among the sixteen turmeric cultivars grown in southern dry zone of Karnataka, Maximum fresh rhizome yield of $33.67 \mathrm{tha}$ ${ }^{1}$ was observed in Salem at par with Rajapuri (32.67 $\left.\mathrm{tha}^{-1}\right)$, Prathibha (32.56 $\left.\mathrm{tha}^{-1}\right)$ and CLT-325 (32.49 $\left.\mathrm{t} \mathrm{ha}^{-1}\right)$, whereas highest cured rhizome yield was exhibited by Salem (8.31 $\left.\mathrm{t} \mathrm{ha}^{-1}\right)$, CLT-325 (7.98 $\left.\mathrm{t} \mathrm{ha}^{-1}\right)$ and Co-1 (7.01 $\left.\mathrm{t} \mathrm{ha}^{-1}\right)$. With respect to quality in terms of curcumin content, PTS-24, Prabha and Prathibha were superior $(7.20 \%, 6.45 \%$ and $6.39 \%$, respectively).

KEY WORDS : Screening, Turmeric, Curcumin, Quality

HOW TO CITE THIS ARTICLE : Salimath, Siddalingayya, Venkatesha, J., Kotikal, Y.K. and Ravirajshetty, G. (2016). Screening of turmeric (Curcuma longa L.) cultivars for quality in Southern dry zone of Karnataka. Asian J. Hort., 11(1) : 186-188, DOI : 10.15740/HAS/TAJH/11.1/186-188. 